\title{
Regulatory peptides in the respiratory tract of Macaca fascicularis
}

\author{
M A GHATEI, D R SPRINGALL, I M RICHARDS, J A OOSTVEEN, R L GRIFFIN, \\ A CADIEUX, J M POLAK, S R BLOOM \\ From the Departments of Medicine and Histochemistry, Royal Postgraduate Medical School, Hammersmith \\ Hospital, London, and the Department of Hypersensitivity Diseases Research, Upjohn Company, Kalamazoo, \\ Michigan, USA
}

ABSTRACT The quantitative distribution and localisation of seven regulatory peptides (vasoactive intestinal peptide (VIP), peptide histidine methionine (PHM), calcitonin gene related peptide (CGRP), galanin, substance $\mathrm{P}$, neuropeptide tyrosine (Y), and bombesin like peptides) were determined by radioimmunoassay and immunocytochemistry in six different regions of the respiratory tract of the cynomolgus monkey, Macaca fascicularis. In general, peptide concentrations were higher in the airways than in lung tissue itself. VIP and PHM were found in greatest abundance and in equimolar concentrations. Concentrations of substance $P$, neuropeptide $Y$, and bombesin were substantially lower. Immunocytochemistry localised all the peptides to nerve fibres, whose density generally paralleled the tissue concentrations by radioimmunoassay except in the case of bombesin, which was not detected. VIP, PHM, and galanin were mostly associated with glands of trachea and bronchus and with blood vessels and smooth muscle; CGRP and substance $P$ were found principally beneath airway epithelium and around smooth muscle fibres and blood vessels; neuropeptide $Y$ was found around blood vessels and seromucous glands only. The pattern of peptide distribution in the Macaca fascicularis respiratory tract is similar to that previously reported in human postmortem material, suggesting that the cynomolgus monkey may be a useful model for examining the pathophysiological role of peptides in human respiratory disease.

The presence of regulatory peptides in the mammalian respiratory tract has received increasing attention during the last decade. ${ }^{1}$ Indeed, there is now accumulating evidence that peptides may have an important regulatory role, both in the normal respiratory tract and in the pathogenesis of some lung diseases. $^{2-13}$

To identify disease related peptide changes, it is important to define the distribution of the various peptides throughout the normal respiratory tract. Most of the currently available data are based on fresh tissue obtained from rodents, ${ }^{2-7}$ cats, ${ }^{5-8}$ and dogs. ${ }^{8}$ In man only postmortem tissue has so far been examined. ${ }^{7-12}$ The relevance of peptide changes extrapolated from these previous studies to human

Address for reprint requests: Professor SR Bloom, Department of Medicine, Royal Postgraduate Medical School, Francis Fraser Laboratory, Hammersmith Hospital, London W120HS.

Accepted 19 December 1986 disease states may be clouded by postmortem changes, or by differences between species.

The aim of this study was therefore to map the distribution of several regulatory peptides in freshly obtained tissue from the respiratory tract of a primate. We report here the distribution of immunoreactivities of vasoactive intestinal peptide (VIP), peptide histidine methionine (PHM), calcitonin gene related peptide (CGRP), galanin, substance $P$, neuropeptide tyrosine (neuropeptide $\mathrm{Y}$ ), and bombesin like peptides in the cynomolgus monkey, Macaca fascicularis.

\section{Methods}

THE RESPIRATORY TRACT TISSUE

Respiratory tract tissue was obtained from five adult Macaca fascicularis monkeys (weight $4-5 \mathrm{~kg}$ ), originally supplied by Charles River or Hazelton Primelab (USA). The animals were killed by intravenous pentobarbitone sodium. The complete respiratory tract 
of each animal was dissected out and divided into upper and lower trachea (full thickness), major bronchus (full thickness), inner lung zone containing medium sized bronchi, middle lung zone containing minor bronchi, and outer areas of lung comprising principally alveoli. Each specimen was subdivided for radioimmunoassay and immunocytochemistry.

Small portions (100-200 mg, including the full thickness of the airways) of each tissue were weighed, diced, and rapidly placed in $0.5 \mathrm{~mol} / 1$ acetic acid $\left(10 \mathrm{ml} / \mathrm{g}\right.$ wet weight of tissue) at $100^{\circ} \mathrm{C}$ for 10 minutes. The extracts were then allowed to cool and stored at $-20^{\circ} \mathrm{C}$ until they were assayed.

\section{RADIOIMMUNOASSAY}

The tissue extracts were thawed and duplicate aliquots of $10 \mu \mathrm{l}$ were assayed for each of the seven peptides. All assays were performed in a total volume of $0.8 \mathrm{ml}$ of $0.06 \mathrm{~mol} / 1$ phosphate buffer, $\mathrm{pH} 7.4$, containing $10 \mathrm{mmol} / 1$ EDTA, $45-450 \mu \mathrm{mol} / 1$ bovine serum albumin, and $20 \mathrm{KIU} / \mathrm{ml}$ aprotinin, and were incubated at $4^{\circ} \mathrm{C}$ for five days. Antibody bound label was separated from free label by adding to each tube $250 \mu \mathrm{l}$ of a suspension containing 2-8 $\mathrm{mg}$ of charcoal (Norit GSX, Hopkin and Williams) coated with clinical grade dextran $(1 \mathrm{~g}: 10 \mathrm{~g}$ of charcoal, average molecular weight 70000 ; Sigma). The tubes were centrifuged at $1600 \mathrm{~g}$ for 20 minutes at $4^{\circ} \mathrm{C}$, followed by immediate separation of the supernatant. Details of each assay are summarised in table 1 .

\section{ANTISERA}

The antisera for radioimmunoassay and immunocytochemistry were raised by multiple subcutaneous injections of peptide conjugates in rabbits. Details of conjugates and antiserum specificities are given in table 1. The antisera to VIP, ${ }^{14}$ PHM, ${ }^{15}$ CGRP, ${ }^{16}$ galanin, ${ }^{17}$ substance $P^{18}$ and neuropeptide $Y^{19}$ showed no cross reaction with any other gut-brain peptides. Antiserum to bombesin ${ }^{20}$ cross reacted fully with mammalian bombesin like peptide $(96 \%$ with gastrin releasing peptide (GRP) and $98 \%$ with the C terminal decapeptide of GRP) and $0.2 \%$ with substance $\mathbf{P}$.

\section{GEL PERMEATION CHROMATOGRAPHY}

To study the various molecular forms of each peptide immunoreactivity present in the respiratory tract, two extracts of trachea were subjected to gel permeation chromatography. Samples (total volume $0.8 \mathrm{ml}$ ) were applied to a column $(1.6 \times 100 \mathrm{~cm})$ containing Sephadex G-50 superfine (Pharmacia) and eluted at a flow rate or $3 \mathrm{ml} / \mathrm{h}$ at $4^{\circ} \mathrm{C}$ with $0.06 \mathrm{~mol} / 1$ phosphate buffer, $\mathrm{pH} 7 \cdot 4$, containing $10 \mathrm{mmol} / 1$ EDTA, $0 \cdot 2 \mathrm{~mol} / 1$ sodium chloride, and $50 \mu \mathrm{mol} / \mathrm{l}$ bovine serum albumin. The column was precalibrated with Dextran blue 2000 (mol wt $2 \times 10^{6}$ ), cytochrome C (mol wt 12384) and ${ }^{125} \mathrm{I} \mathrm{Na}$. Individual pure standard peptides were chromatographed separately to determine their respective elution coefficients (Kav). The marker substances were included in all column runs and fractions representing an elution volume of up to twice the bed volume were assayed for all peptides.

Table 1 Summary of antigen conjugation and antiserum characteristics used in radioimmunoassay and immunocytochemistry

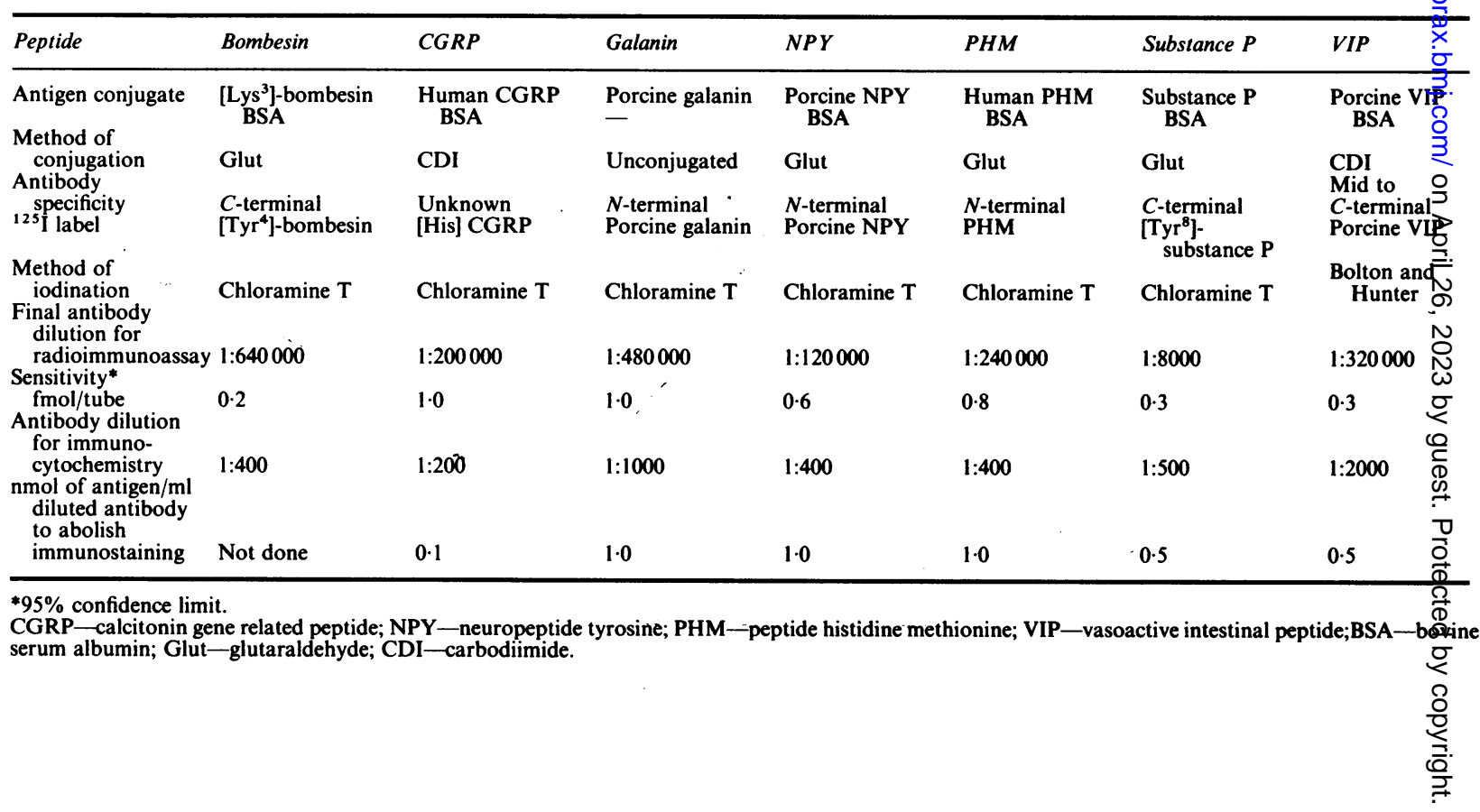


TREATMENT OF DATA

The concentrations of immunoreactive peptides were expressed as $\mathrm{pmol} / \mathrm{g}$ wet weight of tissue and quoted as means with standard errors in parentheses; the significance of the difference between means was calculated by Student's unpaired $t$ test. For comparison of the elution position of the molecular forms of the seven peptides, Kav values were calculated according to the method of Laurent and Killander. ${ }^{21}$

\section{IMMUNOCY TOCHEMISTR Y}

Tissue samples were fixed by immersion in a $0.4 \%$ solution of parabenzoquinone ${ }^{22}$ in $0.05 \mathrm{~mol} / 1$ phos-

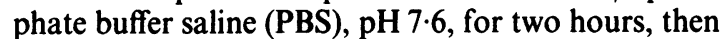
rinsed and stored at $4^{\circ} \mathrm{C}$ in PBS containing $15 \%$ sucrose and $0.01 \%$ sodium azide. Cryostat blocks were prepared and sections $10 \mu \mathrm{m}$ thick were cut from each of the selected areas and immunostained by a modified indirect immunofluorescence method. ${ }^{23}$

Briefly, sections were immersed in PBS containing $0 \cdot 2 \%$ Triton X-100 for 60 minutes before application of primary antibody for 16 hours followed by washing in PBS and reapplication of the antibody for four hours. Antibody dilutions are given in table 1. Fluorescein conjugated goat antirabbit immunogobulin (Miles Laboratories) was used at a dilution of 1:100 for 30 minutes. All washes were performed in PBS. Sections were mounted in glycerol:PBS (9:1) and examined with a Leitz fluorescence microscope. The specificity of the immunostaining results was verified in each case by absorbing the diluted primary antiserum overnight at $4^{\circ} \mathrm{C}$ with the homologous antigen before applying it to tissue sections for immunostaining as above.

\section{Results}

For each peptide radioimmunoassay, the within and between assay variation was less than $10 \%$ and dilution curves of tissue extracts or column peak fractions were parallel to those of pure peptide standards. Table 2 shows the regional distribution of seven peptide immunoreactivities as determined by radioimmunoassay of the tissue extracts. VIP and PHM were found in greatest abundance and in equimolar concentrations in the airways, CGRP, galanin, substance $P$, neuropeptide $Y$, and bombesin like immunoreactivity were found at lower concentrations. In general, all the peptides were most abundant in the upper airways except for bombesin, which showed a more even distribution. Neuropeptide $Y$, substance $P$, and CGRP concentrations were below the detection limit of the assay (table 2).

\section{GEL PERMEATION CHROMATOGRAPHY}

Gel permeation chromatography was performed on two tracheal and bronchial extracts as these areas contained the greatest amounts of peptides; the profiles of galanin, neuropeptide Y, PHM, and CGRP immunoreactivities are shown in figure 1.

The profiles obtained for each peptide showed no significant variation in the elution position of the molecular forms between the different chromatographic analyses. VIP, substance $P$, galanin, and neuropeptide $Y$ like immunoreactivities emerged as major peaks coinciding with pure porcine VIP (Kav $0.52)$, substance $P(K a v=0.92)$, galanin (Kav 0.68), and neuropeptide Y (Kav 0.55) respectively. PHM like immunoreactivity was found to be present in three molecular forms. The first and second peaks (Kav 0.12 and 0.33 ) represented the $N$-terminal extended forms of PHM, ${ }^{15}$ while the third peak (Kav 0.53 ) eluted exactly in the position of synthetic PHM. Most of the CGRP like immunoreactivity was eluted in a similar position to that of synthetic human CGRP, Kav 0.38; and a smaller amount was eluted with a Kav of 0.85 . The nature of this immunoreactive peak is unknown, as synthetic fragments of human CGRP are not commercially available to determine the specificity of the antibody.

Table 2 Distribution of peptides in monkey respiratory tract (pmol/g wet weight of tissue, means with standard errors in parentheses)

\begin{tabular}{|c|c|c|c|c|c|c|}
\hline \multirow[b]{2}{*}{ Peptide } & \multicolumn{2}{|l|}{ Trachea } & \multirow[b]{2}{*}{ Bronchus } & \multicolumn{3}{|l|}{ Lung } \\
\hline & Upper & Lower & & Inner & Middle & Outer \\
\hline $\begin{array}{l}\text { VIP } \\
\text { PHM } \\
\text { CGRP } \\
\text { Galanin } \\
\text { Substance P } \\
\text { NPY } \\
\text { Bombesin }\end{array}$ & $\begin{array}{l}5.7(1.1) \\
7.6(1.1) \\
2.9(0.9) \\
2.5(0.4) \\
1.7(0.4) \\
0.9(0.4) \\
1.1(0.1)\end{array}$ & $\begin{array}{l}6.1(0.5) \\
7.9(0.8) \\
3.1(1.2) \\
2.8(0.1) \\
2.9(0.5) \\
1.0(0.5) \\
1.5(0.4)\end{array}$ & $\begin{array}{l}6.5(0.7) \\
8.0(0.7) \\
4.7(1.6) \\
2.7(0.3) \\
3.6(1.0) \\
2.5(0.7) \\
1.5(0.3)\end{array}$ & $\begin{aligned} & 1.2(0.2) * \\
& 2.5(0.3) \ddagger \\
&<0.3 \\
& 1.3(0.2) \\
&<0.3 \\
&<0.4 \\
& 0.9(0.2)\end{aligned}$ & $\begin{aligned} & 1.8(0.2)^{* *} \\
& 2.5(0.5) \dagger \dagger \\
&< 0.3 \\
& 1.2(0.1) \\
&<0.3 \\
&<0.4 \\
& 1.3(0.2)\end{aligned}$ & $\begin{aligned} & 0.8(0.2) \dagger \\
& 2.1(0.4) \S \\
&<0.3 \\
& 1.3(0.1) \\
&<0.3 \\
&<0.4 \\
& \quad 0.9(0.3)\end{aligned}$ \\
\hline
\end{tabular}

${ }^{*} p<0.01$, upper trachea vs inner lung; ** $<<0.01$, upper trachea vs middle lung; $\nmid p<0.01$, upper trachea vs outer lung; $\ddagger p<0.01$, upper trachea vs inner lung; $t+p<0.01$, upper trachea vs middle lung; $\S p<0.01$, upper trachea vs outer lung. Abbreviations as in table 1 . 

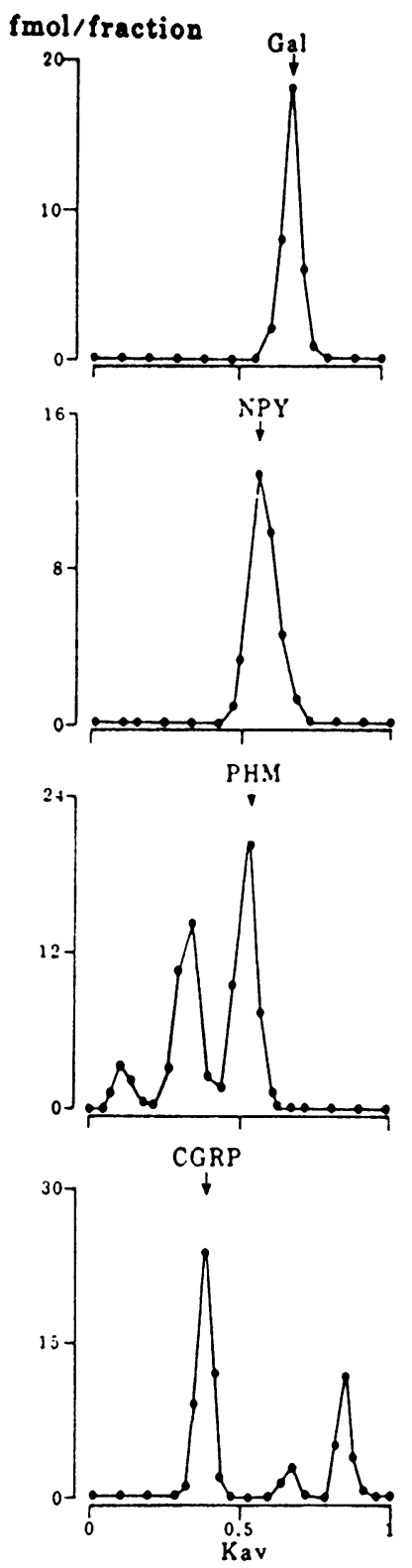

Fig 1 Gel permeation chromatographic pattern profiles of trachea extracts on a column $(1.6 \times 100 \mathrm{~cm})$ of Sephadex G-50 superfine. Gal-galanin; NPY-neuropeptide $Y$; PHM-peptide histidine methionine; CGRP-calcitonin gene related peptide.

\section{IMMUNOCYTOCHEMISTRY}

VIP, PHM, CGRP, galanin, substance $P$, and neuropeptide $Y$ were identified in the tracheobronchial wall of each of the five monkeys examined. The peptides were localised only in nerve fibres, which were more numerous in the upper respiratory tract. The nerves most frequently identified were those contain- $\stackrel{\text { ? }}{+}$ ing VIP, followed by lesser populations of fibres con- $\bar{C}$ taining PHM, CGRP, substance $P$, galanin, and $\overline{\bar{N}}$ neuropeptide $\mathrm{Y}$. According to their distribution, the $\frac{\Phi}{\Phi}$

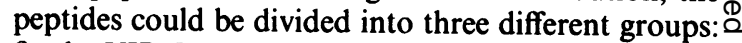
firstly, VIP, PHM, and galanin; secondly, CGRP and substance P; and thirdly, neuropeptide Y. Bombesin $\vec{\circ}$ immunoreactivity was not detected.

Nerve fibres immunoreactive with VIP, PHM, and $\vec{\omega}$ galanin were localised abundantly around the acini of the seromucous glands in the submucosa of both tra- $\vec{x}$ chea and bronchus. They formed a complex network, $\stackrel{\mathbb{N}}{\mathrm{N}}$ which occasionally encompassed almost every individual cell of the acini, and were also seen in great $\vec{\omega}$ numbers around the smooth muscle of the airway and $\overrightarrow{0}$ in the adventitia (figs 2-4). The three peptides were also detected in the nerve fibres surrounding blood $\vec{c}$ vessels (both arteries and veins), including those of the subepithelial layer of the trachea, although less $\overparen{D}$ frequently than fibres containing CGRP and sub- $\overrightarrow{0}$ stance $P$.

In the trachea, CGRP and substance $P$ fibres were seen in the subepithelium (fig 5), mainly associated with small blood vessels, and rarely penetrating the epithelium (fig 6). They were also found in the adventitia, around smooth muscle fibres and in large nerve $\frac{}{\Phi}$ bundles (fig 6). The number of these fibres decreased in the bronchi and was negligible in the intrapulmonary small airways. Scattered positive nerve $\frac{3}{\vec{T}}$ fibres were, however, observed between the media and the adventia of blood vessels (mainly arteries) from the trachea to the lung parenchyma.

Neuropeptide Y was the peptide with the most distinctive distribution. It was found only in nerve fibres circumscribing blood vessels (both arteries and veins) 3 and seromucous glands. Nerves containing neu- $\hat{\partial}$ ropeptide Y (fig 7) were associated with the blood vessels of the entire tracheobronchial tree, from the 0 upper trachea to peripheral bronchi.

\section{Discussion}

In this study seven immunoreactive peptides-VIP, PHM, CGRP, galanin, substance $P$, neuropeptide $Y$, and bombesin-have been detected in the respiratory tract of the cynomolgus monkey, Macaca fascicularis. All the peptides were localised exclusively to the nerve fibres and were generally more abundant in the upper airways.

While most of the peptides, such as neuropeptide tyrosine, ${ }^{7}$ peptide histidine isoleucine (PHI), ${ }^{5}$ substance $P$, and vasoactive intestinal peptide, are present in nerve fibres 368 others, such as adrenocorticotrophic hormone, ${ }^{4}$ the bombesin like peptides, ${ }^{9}$ calcitonin, ${ }^{10}$ and enkephalins, ${ }^{10}$ are found in 


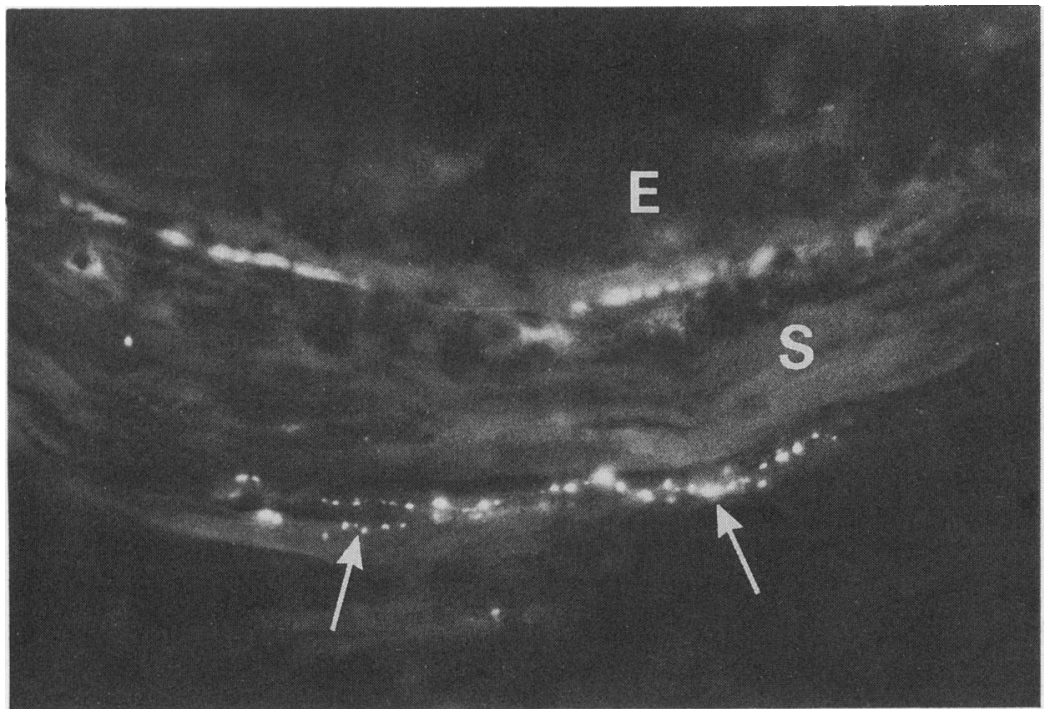

Fig 2 Nerve fibres (arrows) showing vasoactive peptide like immunoreactivity in smooth muscle (S) of stem bronchus (E-epithelium). Indirect immunofluorescence method, $10 \mu \mathrm{m}$ section of tissue fixed in benzoquinone solution.

the endocrine cells. Calcitonin gene related peptide is found in both nerve fibres and mucosal endocrine cells of the rat respiratory tract. ${ }^{2}$

The presence of bombesin like peptides in the endocrine cells of the fetal human bronchial mucosa has been known since 1978. ${ }^{9}$ The low concentration in the adult monkey respiratory tract observed here is consistent with findings in adult rat, guinea pig, and cat. ${ }^{6}$ Although the pattern of distribution in monkey respiratory tract was very similar to that in normal adult human lung obtained at necropsy, the concentrations previously reported in the man are more than three times higher. ${ }^{11}$ Concentrations of bombesin like pep- tides change markedly during growth and development of the human lung, ${ }^{91124}$ and bombesin acts as a growth factor for established small cell bronchial carcinoma. ${ }^{25}$ This group of peptides may therefore have an important role in growth and in tumour promotion in the respiratory tract.

Calcitonin gene related peptide is a recently discovered peptide formed by alternative processing of the calcitonin gene in neural and thyroid tissues. ${ }^{2627}$ CGRP like immunoreactivity is seen throughout the central nervous system and in neurones supplying many peripheral tissues. ${ }^{26-29}$ In rodent respiratory tract considerable amounts have been found in both

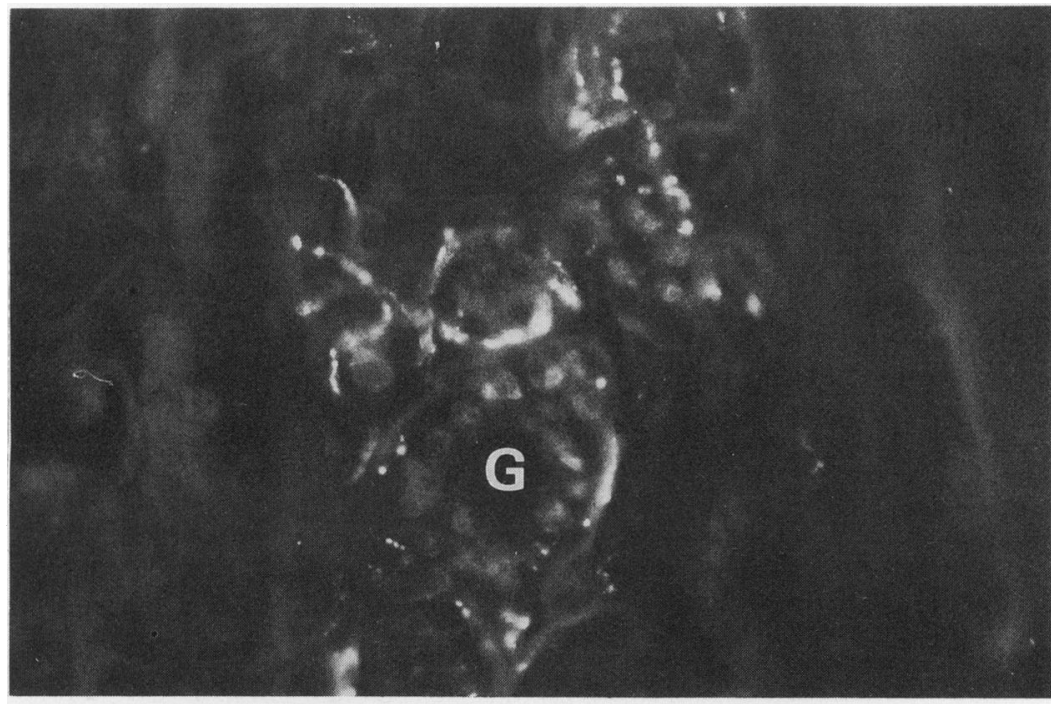

Fig 3 Section of trachea showing nerve fibres immunoreactive for peptide histidine methionine surrounding seromucous glands $(G)$ in the adventitia. Indirect immunofluorescence method, $10 \mu \mathrm{m}$ section of tissue fixed in benzoquinone solution. 


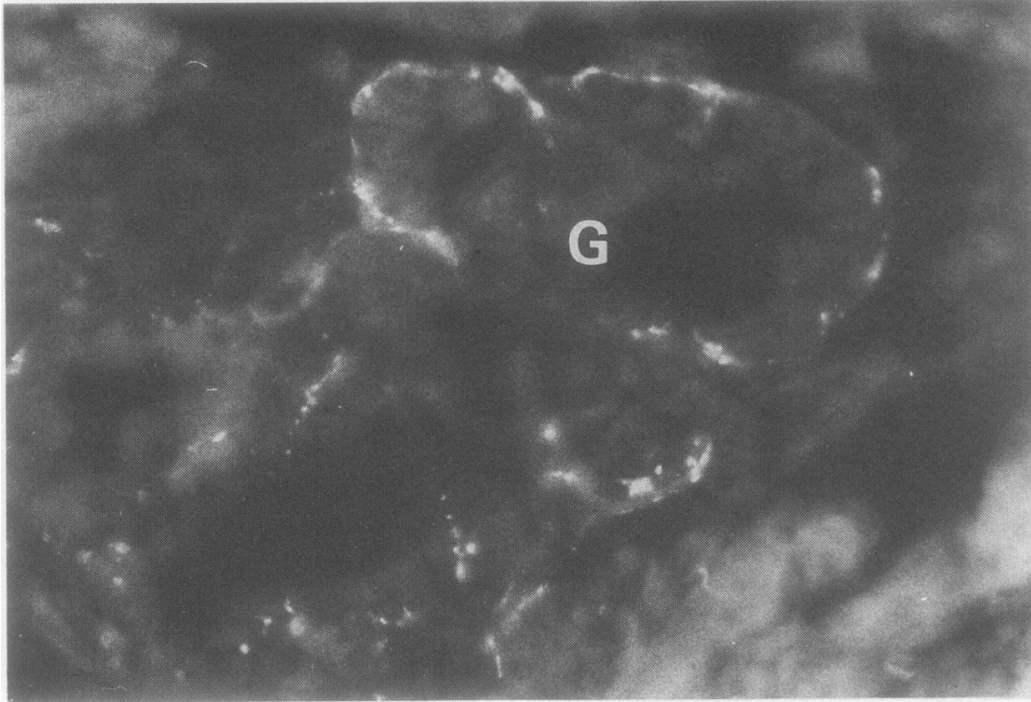

Fig 4 Galanin immunoreactive nerve fibres surrounding seromucous glands $(G)$ in the submucosa of trachea. Indirect immunofluorescence method, $10 \mu \mathrm{m}$ section of tissue fixed in benzoquinone solution.

mucosal endocrine cells and sensory nerve fibres. ${ }^{2}$ The concentration of CGRP in the monkey respiratory tract, however, is at least 30 times less than that reported in the rat and guinea pig, and is comparable to the concentrations found in human upper airways (unpublished observation).

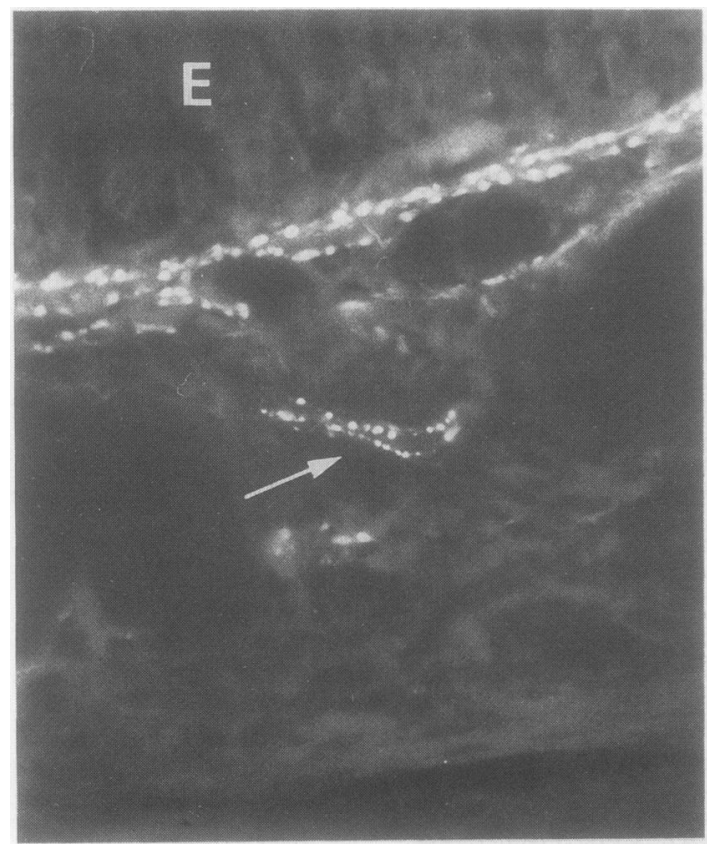

Fig 5 Section of trachea with nerve fibres immunoreactive for substance $P$ (arrow) running below the epithelium $(E)$. Indirect immunofluorescence method, $10 \mu \mathrm{m}$ section of tissue fixed in benzoquinone solution.
The recently discovered peptide histidine methi- $-v$ onine ( 27 amino acid residues) is encoded wth humano vasoactive intestinal peptide messenger RNA $^{30}$ ands differs only by two amino acids from its porcine coun $\frac{\mathrm{J}}{0}$ terpart, peptide histidine isoleucine. ${ }^{31}$ Both PHI and VIP like immunoreactivities have been found in equi-ه্ molar concentrations in most of the tissues exam $\rightarrow \vec{F}$

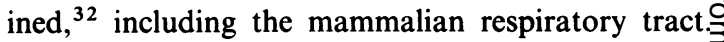
The present study extends these findings to the cynomolgus monkey.

Galanin was first isolated from porcine intestine ${ }^{3}$ and was subsequently found in the central nervouso system $^{34}$ and peripheral tissue. ${ }^{34}{ }^{35}$ It has recently, been localised in the nerve fibres of the mammaliano respiratory tract. ${ }^{36}$ In the monkey lung the distribu tion pattern of galanin like immunoreactivity is veryo similar to that reported in other species. ${ }^{36}$

The pattern of distribution of these regulatory pep? tides in the respiratory tract of Macaca fascicularis is very similar to that observed in man. In both species? VIP and PHM nerves are the most abundant, ${ }^{832} \mathrm{~N}$ followed by lesser populations of fibres containing CGRP, substance $\mathrm{P}^{38}$ and neuropeptide $\mathrm{Y}^{739}$; air ${ }^{N}$ way smooth muscle is supplied by nerves containing galanin and VIP. In the rat, on the other hand, CGRPO is the most widely distributed regulatory peptide andb is present in both nerves and mucosal endocrine cells, ${ }^{2}$ while VIP and PHI-PHM nerve fibres are con? centrated around the seromucous glands of the majoro airways. Moreover, substance $\mathbf{P}$ immunoreactive nerve fibres are very abundant in the rat respiratorys tract and have a distribution similar to that of CGRP $\mathbb{Q}$ Substance $P$, however, is not thought to be present ino the endocrine cells.

These observations highlight two important points 


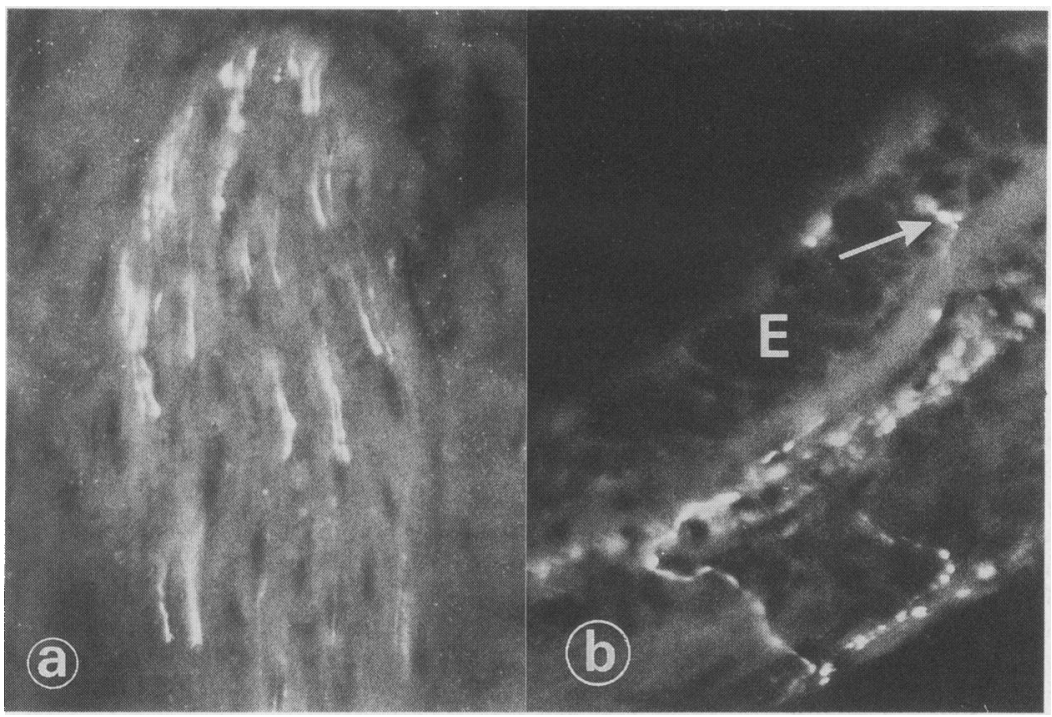

Fig 6 Calcitonin gene related peptide immunoreactive nerve fibres running ( $a$ ) in a nerve bundle in the adventitia of trachea, and ( $b$ ) below the epithelium $(E)$ of a stem bronchus. A fine nerve fibre (arrow) is also seen in the bronchial epithelium in $(b)$. Indirect immunofluorescence method, $10 \mu \mathrm{m}$ section of tissue fixed in benzoquinone solution.

Firstly, peptide distribution in the respiratory tract of primates differs substantially from that of lower mammals such as rodents and, secondly, the distribution in fresh monkey tissue is closely similar to that of human postmortem material. This suggests that deterioration in peptide immunoreactivity in the respiratory tract is relatively trivial for at least several hours after death. An important corollary is that the cynomolgus monkey may be a useful model for examining the role of regulatory peptides in human disease.

There is now extensive evidence that peptides play an important regulatory role in the pathophysiology of asthma. Fibres containing VIP, for example, inner- vate the airways in monkeys (present study) and man. ${ }^{811}$ Inhalation of VIP protects against histamine induced bronchoconstriction in $\operatorname{man}^{13}$ and may be the transmitter mediating the nonadrenergic inhibitory neuronal responses that have been found in baboons ${ }^{40}$ and in human lung tissue ${ }^{4142}$ Other peptides, such as substance $P$, may perform an excitatory function and exacerbate asthma. ${ }^{43-45}$ The distribution of peptides in the rodent appears to differ appreciably from that in man, and rodent models of asthma are therefore unlikely to reflect human disease. ${ }^{4647}$ Non-human primates have been extensively used for the study of human asthma. ${ }^{4849}$ The similarities in the distribution of regulatory peptides in the monkey

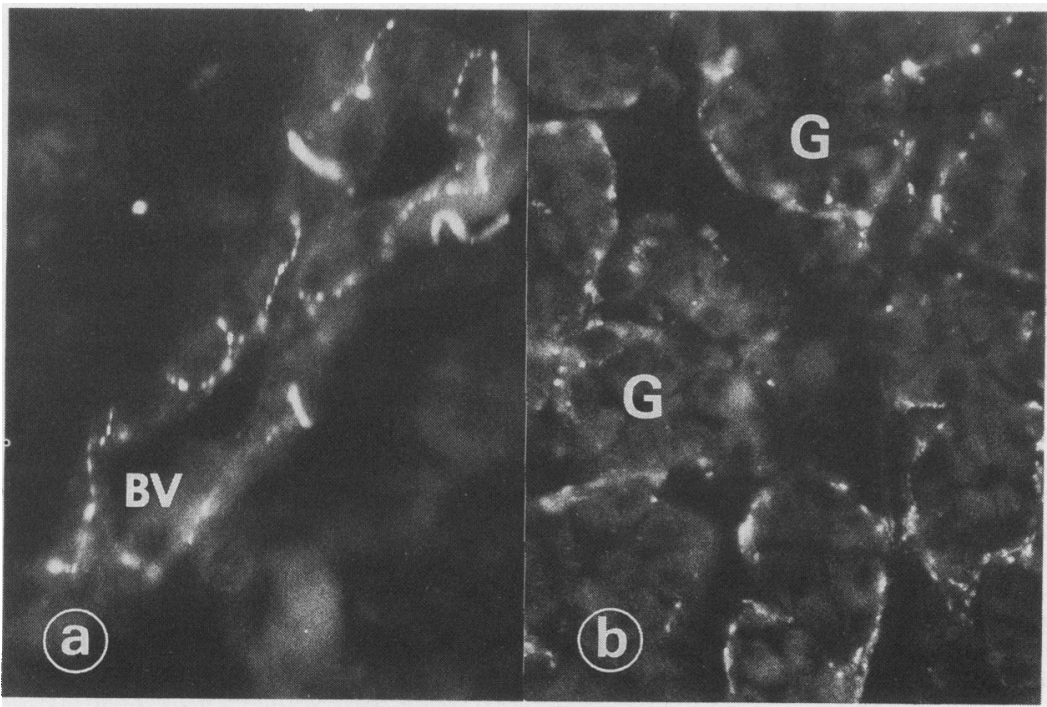

Fig 7 Nerve fibres immunoreactive for neuropeptide $Y(a)$ running along the wall of a blood vessel $(B V)$ in lung, and (b) around seromucous glands $(G)$ in the adventitia of trachea. Indirect immunofluorescence method. $10 \mu \mathrm{m}$ section of tissue fixed in benzoquinone solution. 
and human respiratory tract described in this study further support their use as models of human pulmonary disease.

\section{References}

1 Becker KL. The endocrine lung. In: Becker KL, Gazdar $\mathrm{AF}$, eds. The endocrine lung in health and disease. Philadelphia: WB Saunders, 1984:3-46.

2 Cadieux A, Springall DR, Mulderry PK, et al. Occurrence, distribution and ontogeny of CGRPimmunoreactivity in the rat lower respiratory tract: effect of capsaicin treatment and surgical denervation. Neuroscience 1986;19:605-27.

3 Wharton J, Polak JM, Bloom SR, Will JA, Brown MR, Pearse AGE. Substance P-like immunoreactive nerves in mammalian lung. Invest Cell Pathol 1979;2:3-10.

4 Linnoila RI, Nettesheim P, DiAugustine RP. Lung endocrine-like cells in hamsters treated with diethylnitrosamine: alterations in vivo and in cell culture. Proc Natl Acad Sci 1981;78:5170-4.

5 Christofides ND, Yiangou Y, Piper PJ, et al. Distribution of peptide histidine isoleucine in the mammalian respiratory tract and some aspects of its pharmacology. Endocrinology 1984;115:1958-63.

6 Ghatei MA, Sheppard MN, O'Shaughnessy DJ, et al. Regulatory peptides in the mammalian respiratory tract. Endocrinology 1982;111:1248-54.

7 Sheppard MN, Polak JM, Allen JM, Bloom SR. Neuropeptide tyrosine (NPY): a newly discovered peptide is present in the mammalian respiratory tract. Thorax 1984;39:326-30.

8 Dey RD, Shannon WR jun, Said SI. Localization of VIP immunoreactive nerves in airways and pulmonary vessels of dogs, cats and human subjects. Cell Tissue Res 1981;220:231-8.

9 Wharton J, Polak JM, Bloom SR, et al. Bombesin-like immunoreactivity in the lung. Nature 1978;273: 769-70.

10 Cutz E, Chan W, Track NS. Bombesin, calcitonin and leu-enkephalin immunoreactivity in endocrine cells of human lung. Experientia 1981;37:765-7.

11 Ghatei MA, Sheppard MN, Henzen-Logman S, Blank MA, Polak JM, Bloom SR. Bombesin and vasoactive intestinal polypeptide in the developing lung: marked changes in acute respiratory distress syndrome. J Clin Endocrinol Metab 1983;57:1226-32.

12 Stahlman MT, Kasselberg AG, Orth DN, Gray ME. Ontogeny of neuroendocrine cells in human foetal lung. Lab Invest 1985;52:52-60.

13 Barnes PJ, Dixon CMS. The effect of inhaled vasoactive intestinal peptide on bronchial reactivity to histamine in human. Am Rev Respir Dis 1984;130:162-6.

14 Mitchell SJ, Bloom SR. Measurement of fasting and postprandial plasma VIP in man. Gut 1978;19:1043-8.

15 Yiangou Y, Williams SJ, Bishop AE, Polak JM, Bloom SR. PHM immunoreactivity in plasma and tissue from patients with VIP-secreting tumours and watery diarrhea syndrome. $J$ Clin Endocrinol Metab (in press).

16 Ghatei MA, Stratton MR, Allen JM, Joplin GF, Polak JM, Bloom SR. Co-secretion of calcitonin gene- related peptide, gastrin-releasing peptide and ACTH by a carcinoid tumour metastasising to the cerebellune? Postgrad Med J 1987;63:123-30.

17 Bauer FE, Christofides ND, Hacker GW, Blank MA Polak JM, Bloom SR. Distribution of galanin immus noreactivity in the genitourinary tract of man and ra席 Peptides 1986;7:5-10.

18 McGregor GP, Bloom SR. Radioimmunoassay of sutso stance $\mathrm{P}$ and its stability in tissue. Life Sci 1983 32:655-62.

19 Allen JM, Yeats JC, Adrian TE, Bloom SR. Radiä immunoassay of neuropeptide Y. Regul Pept 198年 8:61-70.

20 Ghatei MA. Bombesin. In: Bloom SR, Long RG, eds Radioimmunoassay of gut regulatory peptides. Londog WB Saunders, 1982:131-7.

21 Laurent TC, Killander J. A theory of gel-infiltration an@ its experimental verification. J Chromatogr 1964: 14:317-30.

22 Bishop AE, Polak JM, Bloom SR, Pearse AGE. A ne $\overrightarrow{\mathrm{w}}$ universal technique for the immunocytochemicat localisation of peptidergic innervation. $J$ Endocrined 1978;77:25-6.

$23 \mathrm{Gu}$ J, Islam KN, Polak JM. Repeated application of the8 first layer antiserum improves immunostaining, a modification of indirect immunofluorescence prob cedure. Histochem J 1983;15:475-83.

24 Johnson DE, Lock JE, Elde RP, Thompson TR. PuF monary neuroendocrine cells in hyaline membrane diơ ease and bronchopulmonary dysplasia. Pediatr Re 1982;16:446-54.

25 Cuttitta F, Carney DN, Mulshine J, et al. Bombesin-like peptide can function as autocrine growth factors in human small cell lung cancer. Nature 1985;316:823-

26 Rosenfeld MG, Mermod JJ, Amara SG, et al. Production of a novel neuropeptide encoded by the calcif tonin gene via tissue specific RNA processing. Nature 1983;304:129-35.

27 Sabate MI, Stolarsky LS, Polak JM, et al. Regulation ơ neuroendocrine gene expression by alternative processing-co-localization of calcitonin and calcitonin-gene related peptide in thyroid C-cells. Biol Chem 1985;260:2589-92.

28 Mulderry PK, Ghatei MA, Rodrigo J, et al. Calcitoni gene-related peptide in cardiovascular tissues of the rat. Neuroscience 1985;14:947-54.

29 Ghatei MA, Gu J, Mulderry PK, et al. Calcitonin gener related peptide (CGRP) in the female rat urogenital tract. Peptides 1985;6:809-15.

30 Itoh N, Obata K, Yanaihara N, Okamoto H. Humad preprovasoactive intestinal polypeptide contains novel PHI-27 like peptide, PHM-27. Natury 1983;304:547-9.

31 Tatemoto K, Mutt V. Isolation and characterisation the intestinal peptide pocrine (PHI) (PHI-27), a new number of the glucagon-secretin family. Proc Nati Acad Sci 1981;78:6603-7.

32 Christofides ND, Polak JM, Bloom SR. Studies on the distribution of PHI in mammals. Peptides 1989 5:261-6.

33 Tatemoto K, Rokaeus A, Jornvall H, McDonald Tr Mutt V. Galanin-a novel biological active peptid 
from porcine intestine. FEBS Lett 1983;164:124-8.

34 Rokaeus A, Melander T, Hokfelt T, et al. A galanin-like peptide in the central nervous system and intestine of the rat. Neurosci Lett 1984;47:161-6.

35 Melander T, Hokfelt T, Rokaeus A, Fahrenkrug J, Tatemoto K, Mutt V. Distribution of galanin-like immunoreactivity in the gastrointestinal tract of several mammalian species. Cell Tiss Res 1985;239:253-70.

36 Cheung A, Polak JM, Bauer FE, et al. Distribution of galanin immunoreactivity in the respiratory tract of pig, guinea pig, rat and dog. Thorax 1985;40:889-96.

37 Uddman R, Sundler F. Vasoactive intestinal polypeptide nerves in human upper respiratory tract. Acta Otolaryngol 1979;41:221-6.

38 Lundberg JM, Hokfelt T, Martling CR, Saria A, Cuello C. Substance P-immunoreactive nerves in the lower respiratory tract of various mammals including man. Cell Tissue Res 1984;235:251-61.

39 Lundberg JM, Terenius L, Hokfelt T, Goldstein M. High levels of neuropeptide $Y$ in peripheral noradrenergic neurones in various mammals including man. Neurosci Lett 1983;42:167-72.

40 Middendorf WF, Russel JA. Innervation of airway smooth muscle in the baboon: evidence for a nonadrenergic inhibitory system. J Appl Physiol 1980; 48:947-56.

41 Richardson JB, Beland J. Nonadrenergic inhibitory nervous system in human airways. J Appl Physiol
1976;41:764-71.

42 Richardson JB. Nonadrenergic inhibitory innervation of the lung. Lung 1981;159:315-22.

43 Nilsson G, Dahlberg K, Brodin E, Sundler F, Strandberg $\mathrm{K}$. Distribution and constrictor effect of substance $P$ in guinea pig tracheobronchial tissue. In: Von Euler US, Pernow B, eds. Substance P. New York: Raven Press, 1977:75-81.

44 Shanahan F, Befus AD, Denburg J, Bienenstock J. Regulatory peptides and mucosal mast cell secretion. Gastroenterology 1983;84:1305.

45 Terenghi G, McGregor GP, Bhuttacharji S, Wharton J, Bloom SR, Polak JM. Vagal origin of substance Pcontaining nerves in the guinea pig lung. Neurosci Lett 1983;36:229-36.

46 Church MK, Warner JO. Sodium cromoglycate and related drugs. Clin Allergy 1985;15:311-20.

47 Richards IM, Dixon M, Jackson DM, Vendy K. Alternative modes of action of sodium cromoglycate. Agents Actions 1986;18:3-4.

48 Patterson R, Talbot $\mathrm{CH}$, Booth BH. Immunoglobulin E-mediated respiratory responses of sub-human primates. Reproducibility and effect of certain pharmacologic agents. Am Rev Respir Dis 1970;102:412-21.

49 Eady RP, Greenwood B, Jackson DM, Orr TSC, Wells E. The effect of nedocromil sodium and sodium cromoglycate on antigen-induced bronchoconstriction in the Ascaris-sensitive monkey. $B r J$ Pharmacol 1985;85:315-25. 